\title{
Introduced Ascidians in Paranaguá Bay, Paraná, southern Brazil ${ }^{1}$
}

\author{
Rosana M. da Rocha ${ }^{2,3}$ \& Laura P. Kremer ${ }^{2,4}$
}

\author{
' Contribution number 1526 of the Departamento de Zoologia, Universidade Federal do Paraná. \\ 2 Laboratório de Ecologia e Sistemática de Ascídias, Departamento de Zoologia, Universidade Federal do Paraná. \\ Caixa Postal 19020, 81531-980 Curitiba, Paraná, Brasil. \\ ${ }^{3}$ Pesquisadora do CNPq. E-mail: rmrocha@ufpr.br \\ ${ }^{4}$ Bolsista do CNPq/PIBIC. E-mail: laurapkremer@gmail.com
}

\begin{abstract}
Exotic (introduced) species are a growing problem in ports worldwide and comprise the most important impacts in marine ecosystems. Periodic monitoring to detect introduced species is extremely important for effective population control. Here we sampled ascidian species near the port of Paranaguá for a taxonomic study of this fauna to attempt to detect introduced species. Larval stages in ascidians are short-lived, and dispersal is restricted to small distances, and so ascidians are very good bioindicators for exotic introductions due to ship transport. Four locations were sampled within Paranaguá Bay (Ilha das Cobras, Pier Tenenge, Ilha do Mel and Ilha da Galheta) and one location outside of the bay (Parque dos Meros). Information for the nearby fauna and for geographic distributions of the species involved was obtained from the literature. Eighteen species were found: Perophora multiclathrata (Sluiter, 1904), Ascidia curvata (Traustedt,1882), A. sydneiensis Stimpson, 1855, Clavelina oblonga Herdman, 1880, Cystodytes dellechiajei (Della Valle, 1877), Eudistoma carolinense van Name, 1945, Distaplia bermudensis van Name, 1902, Didemnum granulatum Tokioka, 1954, Diplosoma listerianum (Milne-Edwards, 1841), Lissoclinum fragile (van Name, 1902), Botryllus planus (van Name, 1902), B. tuberatus Ritter \& Forsyth 1917, Botrylloides nigrum Herdman, 1886, Symplegma rubra Monniot, 1972, Styela canopus (Savigny, 1816), S. plicata (Lesueur, 1823), Microcosmus exasperatus Heller, 1878 and Molgula phytophila Monniot, 1970. The known geographic distributions based on the literature and collections suggest that three species are native, one is a inter-regional introduction, two are introduced from the Pacific and the remaining 12 are cryptogenic.
\end{abstract}

KEY WORDS. Ascidiacea, Tunicata, introduced species, bioinvasion.

RESUMO. Ascídias introduzidas na Baía de Paranaguá, Paraná, sul do Brasil. A crescente presença de espécies introduzidas (exóticas) em portos é um dos maiores problemas ambientais que vêm sendo enfrentados nos ecossistemas marinhos. O monitoramento periódico da fauna é necessário para uma detecção precoce das espécies introduzidas. $O$ objetivo deste trabalho é verificar a presença de espécies não nativas na região de influência do Porto de Paranaguá, por meio de estudo taxonômico da fauna de ascídias desta região. As ascídias possuem larvas de curta duração, fazendo com que sua dispersão natural fique restrita a pequenas distâncias. Assim, os representantes desta Classe podem constituir ótimos bioindicadores para introduções mediadas pelo transporte de grandes navios. Foram realizadas coletas em quatro localidades na Baía de Paranaguá (Illha das Cobras, Píer Tenenge, Ilha do Mel e Ilha da Galheta) e uma fora da Baía (Parque dos Meros) e as informações sobre a fauna de Ascidiacea de outras ilhas próximas, bem como a distribuição geográfica das espécies, foram obtidos na literatura. Identificou-se 18 espécies de ascídias: Perophora multiclathrata (Sluiter, 1904), Ascidia curvata (Traustedt,1882), A. sydneiensis Stimpson, 1855, Clavelina oblonga Herdman, 1880, Cystodytes dellechiajei (Della Valle, 1877), Eudistoma carolinense van Name, 1945, Distaplia bermudensis van Name, 1902, Didemnum granulatum Tokioka, 1954, Diplosoma listerianum (Milne-Edwards, 1841), Lissoclinum fragile (van Name, 1902), Botryllus planus (van Name, 1902), B. tuberatus Ritter \& Forsyth 1917, Botrylloides nigrum Herdman, 1886, Symplegma rubra Monniot, 1972, Styela canopus (Savigny, 1816), S. plicata (Lesueur, 1823), Microcosmus exasperatus Heller, 1878 and Molgula phytophila Monniot, 1970. Levando em consideração a distribuição geográfica da espécie, o registro histórico da região e informações provenientes da literatura conclui-se que três espécies podem ser classificadas como nativas, uma como uma introdução inter-regional, duas como introduzidas e 12 como criptogênicas.

PALAVRAS CHAVE. Ascidiacea, Tunicata, espécies introduzidas, bioinvasão. 
Increasingly, invasive marine species are being reported in ports throughout the world. Such introductions may, and often do, create large environmental problems, such as competition for limited resources, exclusion of native species, the transmission of parasites and diseases, and economic problems, such as those associated with shellfish cultivation. In Tasmania, the introduced predatory seastar (Asterias amurensis) is responsible for the reduction and rarity in bivalve species that live just below or on the sediments in the Derwent Estuary. Impacts on native assemblages, wild fisheries and mariculture operations in areas outside the Derwent Estuary are of immediate management concern (Ross et al. 2003). Another example, the polychaete Terebrasabella heterouncinata arrived as an epizoic on South African abalone imported to California for commercial aquaculture research in 1993. Its unique mechanism of settlement on the outer lip of the shell aperture altered calcium deposition and often severely retarded the growth of infested individuals and economic losses to the industry were considerable (CULVER \& KURIS 2000). The kelp Undaria pinnatifida (Phaeophyceae), native to northeast Asia, was first detected in late 1992 offshore in central Patagonia (Argentina) and is progressively spreading, along with a dramatic decrease in species richness and diversity of native seaweeds in Nuevo Gulf (CASAs et al. 2004). These are only a few recent examples.

Most introductions are new invading species carried by ocean-going vessels, encrusted on their hulls, in their ballast waters or seachests. Therefore, ports are often the principal areas of arrival of new invasive species (CARLton \& GEller 1993, RuIZ et al. 2000, WAsson et al. 2001), though a number of species have been introduced with imported shellfish as epibiotic foulers, an often overlooked transport vector (LAMBERT 2005b). Once arrived, new species may find the areas in and around ports to be favorable for their growth and establishment (calm waters with many man-made structures suitable for colonizing and often nutrient rich due to pollution). In these conditions, invasive species populations often grow quickly.

Ascidians are among the many organisms that are passively transported in this way. As sessile benthic filter-feeders, these species may often find suitable habitat, at least if the port is not estuarine. Also, ascidians are hermaphroditic and often able to self-fertilize, they have rapid growth rates and a long fertile period, and therefore may reproduce at very high rates (BerRill 1975, see review by LAMBERT 2005b). Also, being able to regenerate from fragments (BERRILL \& COHEN 1936, TURON 1992) is another characteristic that favors their establishment in new locations. Many ascidians are viviparous (all colonial and some solitary species) and larvae are protected in incubation sacs or in the tunic during their development, after which they are released to the environment. These larvae are lecithotrophic and have short, free-swimming periods, during which they must find a substrate on which to anchor themselves (Millar 1971, MonNioT et al. 1991). Due to these characteristics, dispersal is limited, while population growth may be rapid. Thus, ascidians have naturally limited distributions, and the widespread appearance of some species may indicate that they have been introduced by man.

Several ascidian species are known as introductions. Perophora japonica, from the northwest Pacific Ocean is now found in Europe (Monniot \& Monniot 1985, Baldock \& Bishop 2001) and in 2003 was found in northern California - a first record for North America (LAMBERT 2005a). Styela clava, also from the northwest Pacific Ocean, is also found in Europe (DAvis \& DAvis 2005 for a recent review) and the United States (LAMBERT \& LAMBERT 1998, 2003). Molgula manhattensis went the other way, originating in the North American Atlantic coast, was found in Japan and Australia in the 1970s, and in Vladivostok in 1999 (Zvyagintsev et al. 2003). Ciona intestinalis, widespread in the Northern Hemisphere, has been introduced into many of the larger ports of the Southern Hemisphere, including both east and west coasts of Australia (KotT 1990, McDonald 2004). In 2002, the southern hemisphere species Corella eumyota was found in the northern hemisphere for the first time, attached to floating docks in two harbors in northwestern France (LAMBERT 2004). Polyandrocarpa zorritensis, originally described in Peru, is now found in the Mediterranean Sea (BRunetri 1978-79, BRunetti \& Mastrototaro 2004), in Japan (Nishikawa et al. 1993) and in California (LAMBERT \& LAMBERT 2003). Atlantic populations of Clavelina lepadiformis have been found in the Mediterranean Sea, transported on the hulls of ships (Turon et al. 2003). From this small compilation, it is clear that ascidians have been carried distances both small and large, between hemispheres and throughout the world. Species of any Order, solitary and colonial, are all subject to transportation and introduction.

In the state of Paraná, the port of Paranaguá $\left(25^{\circ} 30,1^{\prime}\right.$ S; $48^{\circ} 31,0^{\prime} \mathrm{W}$ ), the most important port in southern Brazil, receives ships that transport grain (mostly soy), chemicals, oil and industrial goods from and to many parts of the world. The number of ships passing through this port each year is growing annually: from 1,737 ships in 2000 to 2,204 in the year 2004 (http:/ /www.pr.gov.br/portos, in 11/24/2005). In March 2001 a toxic algae bloom occurred near Laranjeiras Bay (within Paranaguá Bay), and was the first ever reported, causing serious economic impact on the local fishing industry (L. F. Fernandes 2001, personal communication). Coscinodiscus wailesii is another new algal species for South American, and recently found in Paranaguá Bay (Fernandes et al. 2001). A species of ascidian (Bostricobranchus digonas, Abbott 1951) was described from Florida, in the United States, and was also found in Paranaguá Bay probably introduced, since it has not yet been found again on subsequent attempts (Rocha 2002). Thus, Paranaguá Bay is now host to a variety of introduced species. In Brazil, eight species of ascidians were potentially introduced in the historical past: Ciona intestinalis, Phallusia nigra, Didemnum perlucidum, Diplosoma listerianum, Microcosmus exasperatus, Styela canopus, Styela plicata and Symplegma brakenhielmi.

With these considerations, our goal in this study was to sample the ascidian community in the area of influence of the 
Port of Paranaguá. Specifically, we wished to use ascidians as indicator species to better understand the biology of species introductions due to shipping in marine systems.

\section{MATERIAL AND METHODS}

Five locations were sampled within and near Paranaguá Bay (Fig. 1): Ilha das Cobras $\left(25^{\circ} 29,00^{\prime} S ; 48^{\circ} 25,50^{\prime} \mathrm{W}\right)$ and Pier Tenenge $\left(25^{\circ} 32,84^{\prime} \mathrm{S} ; 48^{\circ} 21,51^{\prime} \mathrm{W}\right)$, sampled on 7 December 2003 ; Ilha da Galheta $\left(25^{\circ} 35,00^{\prime} \mathrm{S} ; 48^{\circ} 19,00^{\prime} \mathrm{W}\right)$ on 11 March 2004; Ilha do Mel $\left(25^{\circ} 33,00^{\prime}\right.$ S; $\left.48^{\circ} 18,00^{\prime} \mathrm{W}\right)$ on 11 March 2004 and 9 June 2005; and Mero Park (25 43,00' S; $48^{\circ} 20,00^{\prime}$ W) on 14 May 2005. Ascidians were collected by scuba diving at depths of up to four meters, except Mero Park, where depths reached a maximum of $17 \mathrm{~m}$. Samples were anesthetized and fixed in 10\% neutralized formalin.

Since historical records of ascidian species are scarce, we decided whether species were native, introduced or cryptogenic (of unknown status) based on their published geographic records, by exhaustively searching the literature for all publications that included distributional (latitude and longitude) information, along with habitat and substrate type, for all of the ascidian species encountered. Cryptogenic species were considered to be those species with widespread distributions and without information of known native distributions in the literature, as well as Atlantic species with disjunct distributions between northern and southern hemispheres. We considered introduced species as those with worldwide distributions but are either unknown from northeastern Brazil, or have strong indications of introduction in other locations in the literature, or only occur on artificial substrates in southern Brazil.

\section{RESULTS}

Eighteen species (Tab. I) were collected, with 30 samples from Ilha das Cobras, 26 from Pier Tenenge, nine from Ilha do Mel, 11 from Ilha da Galheta and five from Parque dos Meros. Only six samples were of solitary animals, collected at Ilha da Galheta, Ilha do Mel and Mero Park. Some samples in the family Didemnidae are still unidentified, since larvae (which have characters of critical importance in species identification) were absent.

Four distinct distribution patterns were found for this ascidian community. First are the endemics and included only one species, Molgula phytophila (Fig. 2). Next, species found from the Caribbean to southern Brazil (Ascidia curvata, Eudistoma carolinense, Botryllus planus; Figs 3-5). Third, species found in the Caribbean and in southern Brazil, but not recorded in northeastern Brazil (Ascidia sydneiensis, Styela plicata; Figs 6-10). Fourth, very widespread species, which we call cryptogenic (Clavelina oblonga, Distaplia bermudensis, Cystodytes dellechiajei, Didemnum granulatum, Lissoclinum fragile, Diplosoma listerianum, Perophora multiclathrata, Botrylloides nigrum, Botryllus tuberatus, Symplegma rubra, Styela canopus, Microcosmus exasperatus; Figs 11-19).

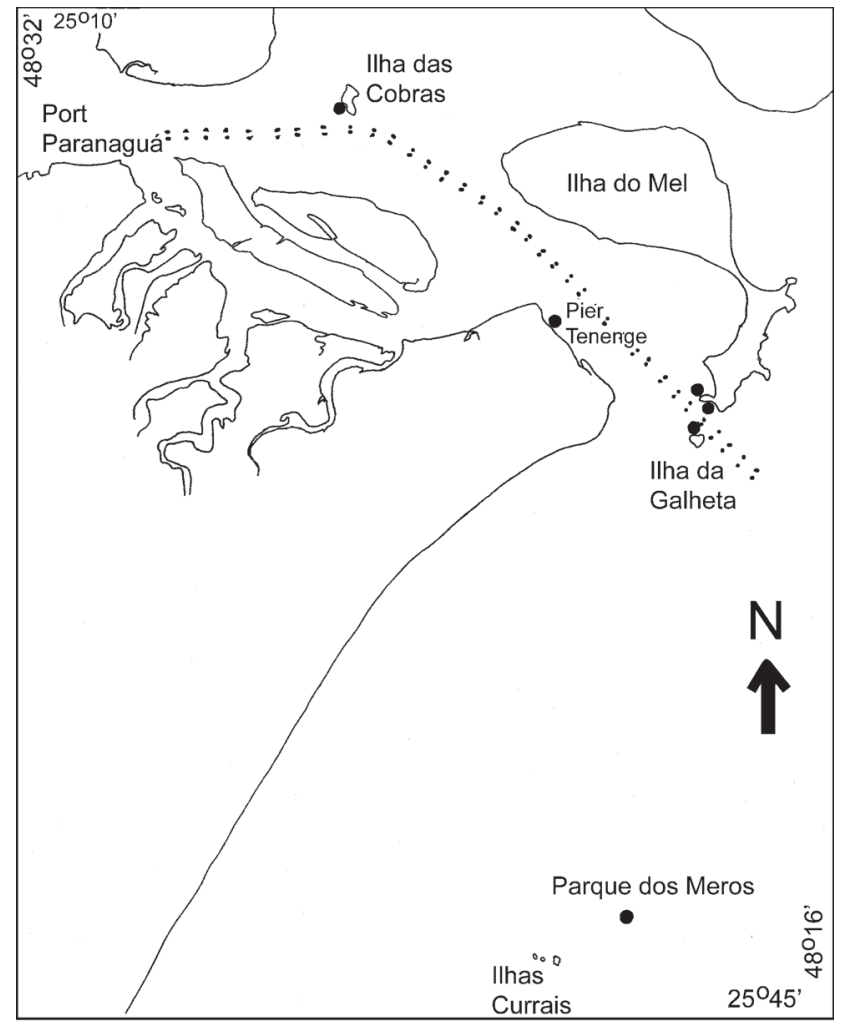

Figure 1. Map of the region of Paranaguá Bay, and collecting locations (marked with black circles). The dotted line indicates the canal through which cargo ships pass on their way to port.

\section{DISCUSSION}

Molgula phytophila, the only endemic species in the region (Fig. 2, Tab. II), was found encrusted on fish-nets in the concrete blocks that form the artificial reef in Mero Park. It is quite possible that this species is synonymous with $M$. braziliensis Millar, 1958, but the type specimen (London Natural History Museum) of the latter is of poor quality and cannot be used for identification of the former. If synonymous, the specimen in Millar (1958) would be the first recorded in the Brazilian coast.

Ascidia curvata, Eudistoma carolinense and Botryllus planus have a continuous distribution from the Caribbean to our study area, and also present some records in North America (Figs 3-5, Tab. II). This distribution suggests that these species are native, with a distribution that includes the western Atlantic Ocean. However, the status of the species with this distribution has been debated. The Caribbean fauna should extend only to the Brazilian state of Espírito Santo, following Palácio (1982), who considered the region between Espírito Santo and the southernmost Brazilian state of Rio Grande do Sul, as a region of high endemism and therefore a biogeographical province. 
Table I. List of the species and occurrences at each sampling site.

\begin{tabular}{|c|c|c|c|c|c|}
\hline & Ilha das Cobras & Pier Tenenge & Ilha do Mel & Ilha Galheta & Parque dos Meros \\
\hline \multicolumn{6}{|l|}{ Perophoridae } \\
\hline Perophora multiclathrata (Sluiter, 1904) & $X$ & & & & \\
\hline \multicolumn{6}{|l|}{ Ascidiidae } \\
\hline Ascidia curvata (Traustedt, 1882) & & & & $\mathrm{x}$ & \\
\hline Ascidia sydneiensis Stimpson, 1855 & & & & $x$ & \\
\hline \multicolumn{6}{|l|}{ Clavelinidae } \\
\hline Clavelina oblonga Herdman, 1880 & $x$ & $\mathrm{x}$ & $x$ & $x$ & \\
\hline \multicolumn{6}{|l|}{ Polycitoridae } \\
\hline Cystodytes dellechiajei (Della Valle, 1877) & & & & $x$ & \\
\hline Eudistoma carolinense van Name, 1945 & & & $x$ & $x$ & \\
\hline \multicolumn{6}{|l|}{ Holozoidae } \\
\hline Distaplia bermudensis van Name, 1902 & $x$ & $x$ & & & \\
\hline \multicolumn{6}{|l|}{ Didemnidae } \\
\hline Didemnum granulatum Tokioka,1954 & & $\mathrm{x}$ & $x$ & & \\
\hline Diplosoma listerianum (Milne-Edwards, 1841) & & & & $x$ & \\
\hline Lissoclinum fragile (van Name, 1902) & & $\mathrm{x}$ & & & \\
\hline \multicolumn{6}{|l|}{ Styelidae } \\
\hline Botryllus planus (van Name, 1902) & $\mathrm{X}$ & $\mathrm{x}$ & & & \\
\hline Botryllus tuberatus Ritter e Forsyth, 1917 & & & & $\mathrm{x}$ & $x$ \\
\hline Botrylloides nigrum Herdman 1886 & & & $x$ & & \\
\hline Symplegma rubra Monniot C., 1972 & $x$ & $x$ & & $x$ & \\
\hline Styela canopus (Savigny, 1816) & & & & & $x$ \\
\hline Styela plicata (Lesueur, 1823). & & & $x$ & & \\
\hline \multicolumn{6}{|l|}{ Pyuridae } \\
\hline Microcosmus exasperatus Heller, 1878 & & & & & $x$ \\
\hline \multicolumn{6}{|l|}{ Molgulidae } \\
\hline Molgula phytophila Monniot, 1969-70 & & & $x$ & & $x$ \\
\hline
\end{tabular}

However, a study of the gastropod community did not support this hypothesis, since endemism was not high within these latitudes, which should therefore only be considered a region of transition (Floeter \& Soares-Gomes 1999). Also, the Brazilian Current reaches the state of Santa Catarina, providing a dispersal route and explaining southern ascidian distributions. In the north, the Gulf Current of the Caribbean works in the same way, carrying ascidians along and thereby explaining northern distribution patterns and the similarities between Bermuda and Caribbean ascidian faunas (Monniot \& MonNiot 1983).

Ascidia curvata was first reported as adults in Brazil in Paraná (Rocha \& NASSER 1998) while juveniles were collected in São Paulo in the 1990s that may be this species (RMR, unpublished data). Eudistoma carolinense was first reported in Brazil on the coast of the state of Pará (Millar 1977). This species has never been reported on artificial substrates, and thus may be classified as native, at least in northeastern Brazil. On the other hand, the lack of records of this species in the states of Rio de
Janeiro and São Paulo, suggests that the southern distribution may be explained by human transport. Botryllus planus was first reported in Brazil in Rio de Janeiro and São Paulo (Costa 1969). Ascidia sydneiensis and Styela plicata, all from other regions in the world, have disjunct distributions (type three) and so were considered introduced in Paraná (Figs 6-7, Tab. II). In Brazil, they have only been reported from the south and southeast with one report of S. plicata from Bahia (T. LOTUFO 2002, personal communication). Ascidia sydneiensis (first reported in São Paulo, BJORnBERG 1956) is rare in southeastern and southern Brazil and is almost never found on natural substrates (the exception being this study - the only individual was found underside a small boulder at Ilha da Galheta). The few other reports are on artificial substrates, such as ship hulls (Millar 1958) and in shellfish cultivation (Rocha, unpublished observations on shells of Nodipecten nodosus (Linnaeus, 1758) at Penha, Santa Catarina). It was also introduced in Guam (Lambert 2003), Papeete (Monniot et al. 1985), Sierra Leon (Millar 1956, Monniot \& Monniot 1994). 

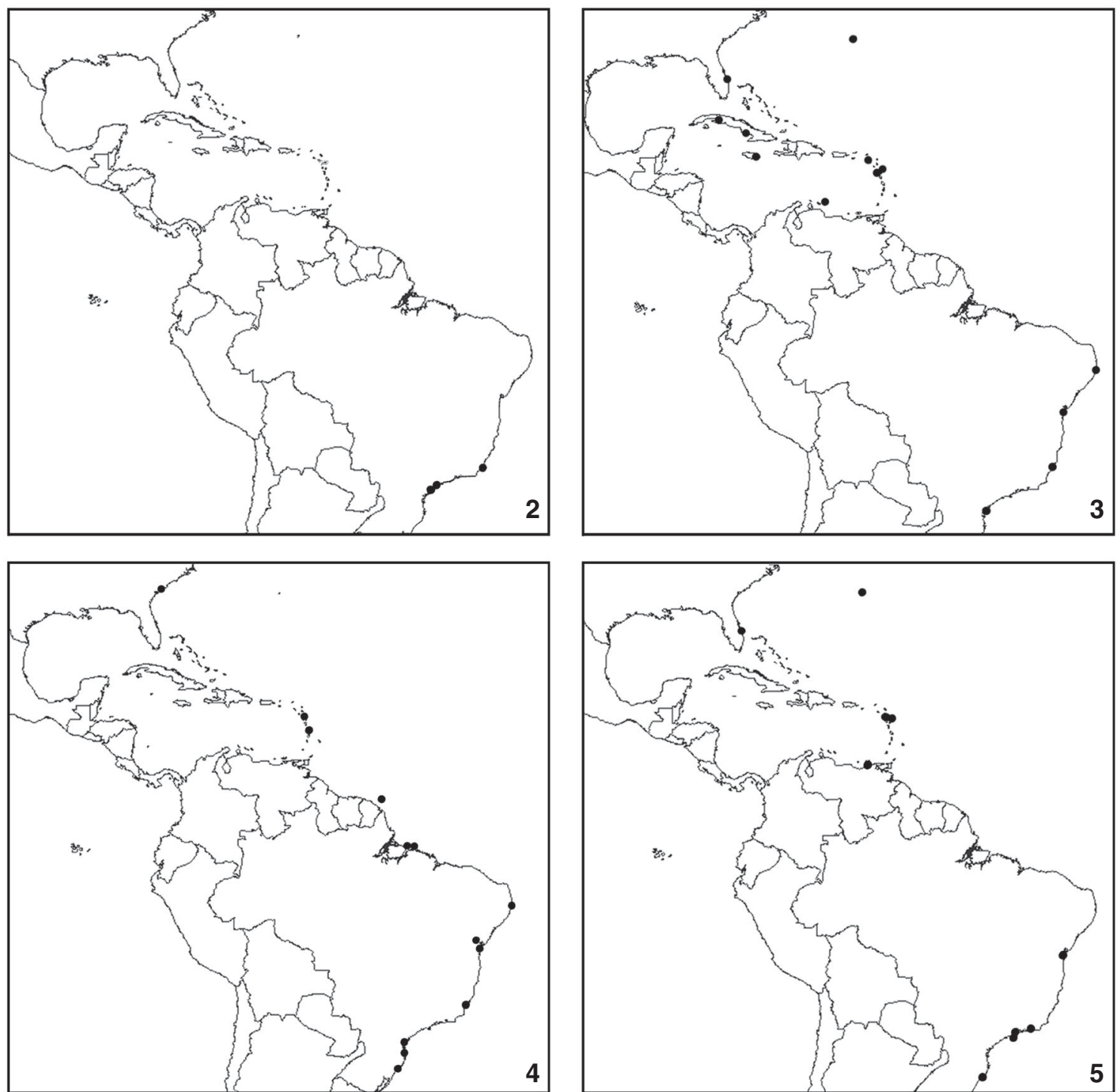

Figures 2-5. Distributions of the species found in Paranaguá Bay and nearby, with exclusive Atlantic distributions: (2) Molgula phytophila; (3) Ascidia curvata; (4) Eudistoma carolinense; (5) Botryllus planus.

Styela plicata is included with the "ascidan fauna inhabiting harbours and other largely man-made habitats throughout the tropical oceans" (Monniot \& Monniot 1997). This species has been found in Brazil since the $19^{\text {th }}$ century, with a record by TRAustedt (1883) in Rio de Janeiro. The reason to include it as an introduced species is its rarity on natural substrates and its absence in northeastern Brazil (except for one individual in Marina de Aratu, Bahia; T. Lotufo 2002, personal communicaton). Also, it is very common on artificial substrates in Rio de Janeiro, where it is one of the commonest fouling organisms on buoys and other floating structures (A. JUNQUEIRA 2005, personal communication). It is also very common on mussels in cultivation and on nets used for oyster cultivation in the state of Santa Catarina, where it may occur in such large quantities that may cause competition with mussels and oysters as well as creating the need for costly cleaning of the cultivation structures. In São Sebastião, São Paulo, this ascidian was found on fishing nets (RoDRIGUEs 1962), and only once on natural substrates (RосHA, non published observation). Interestingly, it was first described based on a sample taken from a ship hull in Philadelphia, Pennsylvania, in the United States, while not being found on natural substrates in the same region (VAN NAME 1945). Proof that this species travels on ship hulls is plentiful: "...from the bottom of the USS Palos after a Voyage across the Pacific from China or Japan" (Токіока 1967).

Twelve species are cryptogenic: Clavelina oblonga, 
Table II. List of ascidian species, and where found, on the Brazilian coast.

\begin{tabular}{|c|c|c|c|c|c|c|c|c|c|c|c|c|}
\hline \multirow{2}{*}{ Species } & \multicolumn{11}{|c|}{ Coastal Brazilian State } & \multirow{2}{*}{ References } \\
\hline & SC & PR & SP & $\mathrm{RJ}$ & ES & BA & $\mathrm{AL}$ & PE & RN & CE & PA & \\
\hline Perophora multiclathrata & & & $x$ & & $x$ & & $x$ & & & & & 11,13 \\
\hline Ascidia curvata & & $x$ & & & $x$ & $x$ & & $x$ & & & & 10,13 \\
\hline Ascidia sydneiensis & $x$ & $x$ & $x$ & $x$ & & & & & & & & $2,3,4,10,11,14$ \\
\hline Clavelina oblonga & $x$ & $x$ & $x$ & $x$ & $x$ & & & & & & & $2,3,4,8,10,11,13,14,15$ \\
\hline Cystodytes dellechiajei & $x$ & $x$ & & $x$ & & $x$ & $x$ & $x$ & $x$ & $x$ & $x$ & $1,7,10,13,14,15$ \\
\hline Eudistoma carolinense & $x$ & & & & $x$ & $x$ & & $x$ & & $x$ & $x$ & $7,12,13,15$ \\
\hline Distaplia bermudensis & $x$ & $x$ & $x$ & $x$ & $x$ & & & & & & $x$ & $3,7,8,10,11,13,14,15$ \\
\hline Didemnum granulatum & $x$ & $x$ & $x$ & & & $x$ & & & $x$ & $x$ & & $9,11,13,15$ \\
\hline Diplosoma listerianum & $x$ & $x$ & $x$ & $x$ & $x$ & $x$ & $x$ & $x$ & $x$ & & & $8,10,11,12,13,15$ \\
\hline Lissoclinum fragile & $x$ & & $x$ & $x$ & & & & $x$ & & $x$ & & $11,13,15$ \\
\hline Botryllus planus & & & $x$ & $x$ & & $x$ & & & & & & 6,13 \\
\hline Botryllus tuberatus & $x$ & & $x$ & $x$ & & & $x$ & $x$ & $x$ & & & $3,8,11,13,15$ \\
\hline Botrylloides nigrum & $x$ & & $x$ & $x$ & $x$ & $x$ & $x$ & $x$ & & & & $4,8,11,13,14,15$ \\
\hline Symplegma rubra & & $x$ & $x$ & $x$ & $x$ & & & & & & & $8,10,11,13,14$ \\
\hline Styela canopus & & & $x$ & $x$ & & $x$ & & $x$ & $x$ & & & $5,11,13$ \\
\hline Styela plicata & $x$ & & $x$ & $x$ & & $x$ & & & & & & $1,2,3,4,5,11,13,14$ \\
\hline Microscosmus exasperatus & $x$ & $x$ & $x$ & $x$ & $x$ & $x$ & $x$ & $x$ & & & & $1,2,3,4,7,10,11,13,14,15$ \\
\hline Molgula phytophila & $x$ & $x$ & & $x$ & & & & & & & & 5,12 \\
\hline
\end{tabular}

1) van Name (1945), 2) Bjornberg (1956), 3) Millar (1958), 4) Rodrigues (1962), 5) Monniot (1969/70), 6) costa (1969), 7) Millar (1977), 8) Rodrigues \& Rocha (1993), 9) Rocha \& Monniot (1995), 10) Rocha \& Nasser (1998), 11) Rodrigues et al. (1998), 12) Rocha \& Moreno (2000), 13) T. Lotufo, personal communication (2002), 14) Rocha \& Costa (2005), 15) Rocha et al. (2005).

Distaplia bermudensis, Cystodytes dellechiajei, Didemnum granulatum, Lissoclinum fragile, Diplosoma listerianum, Perophora multiclathrata, Botrylloides nigrum, Botryllus tuberatus, Symplegma rubra, Styela canopus and Microcosmus exasperatus. Of these, Clavelina oblonga, Distaplia bermudensis and Symplegma rubra also have disjunct distributions: southern and southeastern Brazil, as well as the Caribbean and North America (Figs 8-10, Tab. II). While this distribution is quite similar to that of clearly introduced species, the lack of information for these species causes us to tentatively call them cryptogenic. Though few studies have taken place on the northeastern Brazilian coast, these species are quite easily encountered and identified. If they occurred in that region, it is very likely that they would have been recorded. Thus, while probably introductions, it is difficult to determine in which direction the introductions went from north to south, or vice versa. It is believed that they are native to the western Atlantic; the few encounters in other continents are considered introductions.

Clavelina oblonga, according to vAN NAME (1945) referring to the material Hartmeyer collected in São Sebastião, São Paulo, was first recorded in Brazil in 1910. Clavelina oblonga is also found near Dakar, Senegal, and at Ilha Faial, Azores. In the Azores, it was introduced from American populations in 1971, and is restricted to Horta Harbor (MоNNIOT \& MonNiot 1994).
The first record for Distaplia bermudensis in Brazil is that of Millar (1958), at Ubatuba, São Paulo. Pérès (1957) recorded this species in the Mediterranean Sea (Baleares Islands), but possibly erroneously identified. It was perhaps Distaplia rosea Della Valle, 1881, common in the Mediterranean. Since this species is only found on natural substrates it is probably native, and therefore should be carefully studied (substrate, location, etc.) in future Brazilian studies to clarify its status.

Symplegma rubra was first recorded in 1993 in São Sebastião, São Paulo, Brazil (Rodrigues \& Rocha 1993). However, Rodrigues (unpublished data) encountered this species in the region since the 1960s.

The remaining cryptogenic species are widely distributed in the world and the entire Brazilian coast (the fourth distribution pattern; Figs 11-19, Tab. II). Thus it is difficult to determine the origin of these species and their points of introduction.

Perophora multiclathrata has been recorded three times in Brazil, the first of which was Rodrigues et al. (1998). It is possibly distributed throughout the Brazilian coast, but being a cryptic species, is not easily found. It was found only once in the collections from Paranaguá Bay, along with Botryllus planus. LAMBERT (2003) also classified this species as cryptogenic in Guam. 

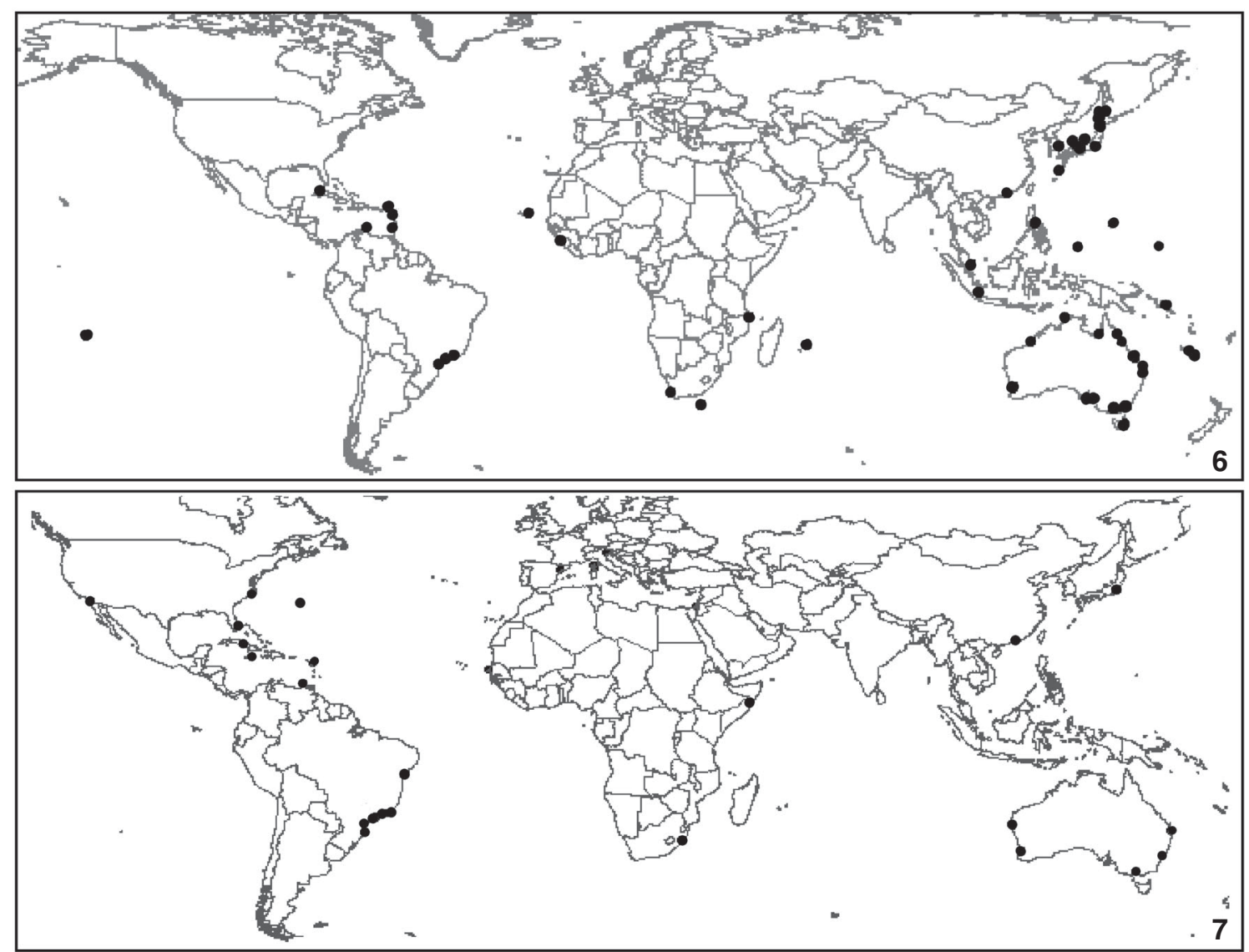

Figures 6-7. Distributions of the species found in Paranaguá Bay and nearby, that have widespread distributions and are disjunct in the western Atlantic: (6) Ascidia sydneiensis; (7) Styela plicata.

The first record for Cystodytes dellechiajei on the Brazilian coast was Herdman (1886, in Millar 1958), probably in Bahia, with the name $C$. draschii, that today is considered synonymous with $C$. dellechiajei. LAMBERT (2003) considered this a native species in Guam, because it was found predominantly on natural substrates. This is a difficult species to identify due to the extreme contraction of the zooids during fixation, and due to its relatively uniform morphology throughout its geographic distribution. In the Mediterranean, however, several morphotypes exist, most of which vary in color and spicule composition. Genetically, six clades are recognized, but which do not correspond with spicule shape and only partially with color (LopezLegentil \& Turon 2005). These results make it impossible to determine new species, but they indicate that $C$. dellechiajei may not be just one, widespread, species as it is considered today.

Didemnum granulatum was found first in Brazil (São Paulo) in 1995 (Rocha \& MonNiot 1995), and on the west African coast (Senegal) in 1994 (Monniot \& Monniot 1994). This species has not been found in the Caribbean, nor on the eastern coast of Africa, and thus we believe it to be of Pacific origin.
Lissoclinum fragile was first recorded in Brazil by RoDRIGUES et al. (1998) in São Paulo. The fact that it is found in ports, such as Apra Harbour, Guam (Monniot \& Monniot 2001), Noumea port in New Caledonia (MonNIOT 1992), Malakal Harbor in Palau an also harbors in Honolulu, Hawaii (G. LAMBERT 2005, personal communication) suggests that it may be passively transported by ships. L. fragile is also considered introduced in Tahiti (MonNiot et al. 1985) and was first reported on the west African coast in 1994 (MonNiot \& Monniot 1994).

Diplosoma from northeastern Brazil has been considered Diplosoma macdonaldi but this species is synonymous with $D$. listerianum (Rowe 1966) and the first record for Brazil was in the 1800s (Herdman 1886) in the state of Bahia. This species was first described from the English Channel by Milne-Edwards in 1841 but it is so widely distributed throughout the Atlantic, Indian and Pacific Oceans that it is difficult to define which is its actual native distribution. Diplosoma listerianum is recognized as introduced in Papeete, Tahiti (MonNiot et al. 1985), Guam (LAMBERT 2002), and a historical record of observations and quantitative information for the last 25 years at a series of 


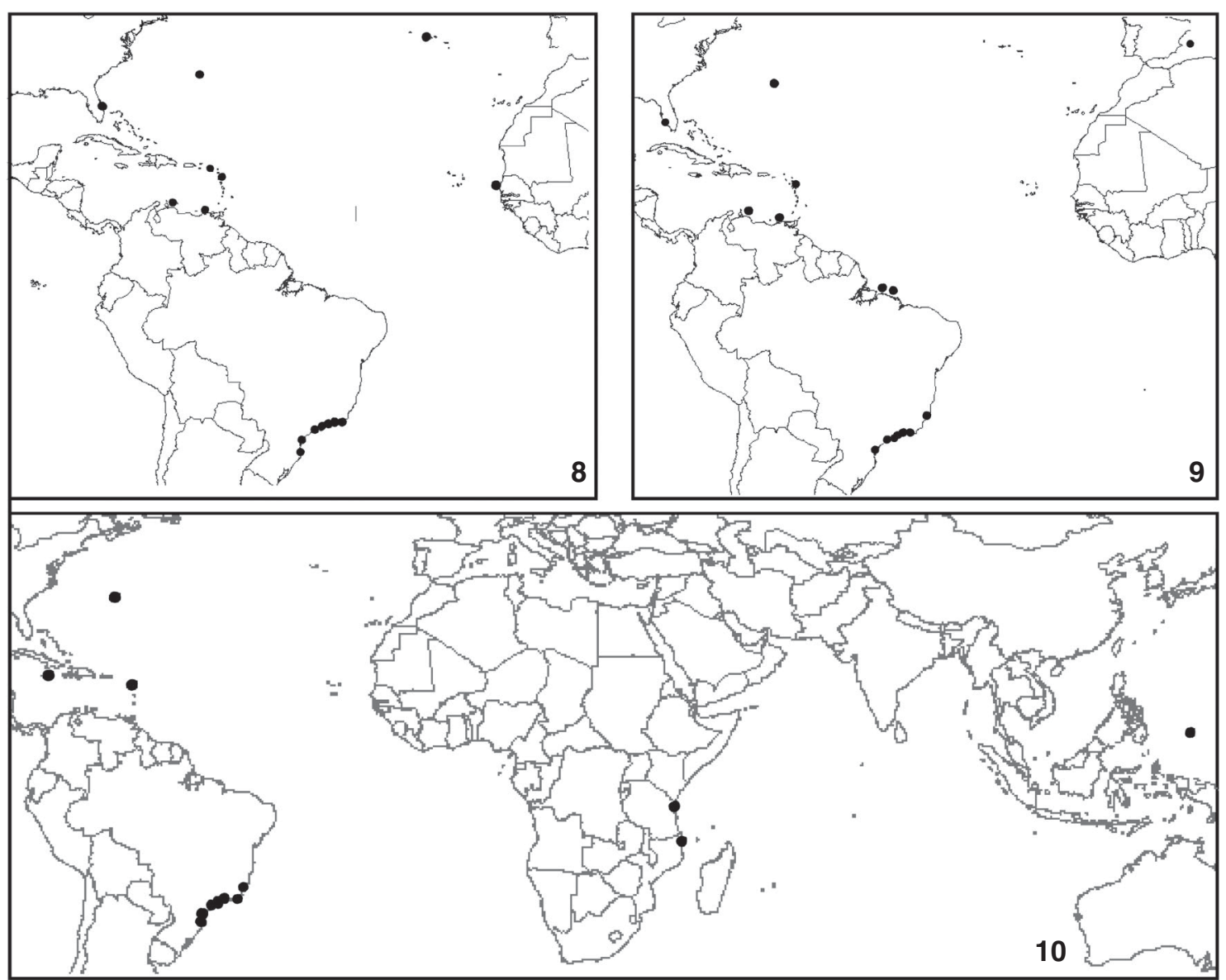

Figures 8-10. Distributions of the species found in Paranaguá Bay and nearby, with disjunct distributions in the western Atlantic and some records outside the Atlantic: (8) Clavelina oblonga; (9) Distaplia bermudensis; (10) Symplegma rubra.

sites in the southwestern Gulf of Maine showed that it is a recent introduction there (HARRIS \& TYrReLl 2001). This species forms chimera (an association of genetically different individuals within the same colony), and may store exogenous spermatozoids for several weeks. These characters favor the colonization of new areas (Sommerfeldt \& Bishop 1999, Lambert 2001). Studies in São Paulo demonstrated other adaptations that favor introduction: recruitment throughout the year, great ability to colonize artificial substrates, rapid growth rates, and rapid sexual maturity (within one month; RосHA 1991).

Botryllus tuberatus (under the name B. primigenus Oka, 1928) was first reported on the Brazilian coast in São Paulo and Rio de Janeiro (Millar 1958). This species is very different from the other botryllids by having only four rows of stigmata and it is likely that other species that also have four rows of stigmata have been designated as this species. Colonies vary in both form and color (MоNNIOT 2002). Котт (1985) considered its distribution unusual, since it is very rare for a species of the western Pacific. In both Paraná and Santa Catarina, large colo- nies have been found, greater than $20 \mathrm{~cm}$ in diameter, and on natural vertical substrates. If this is an introduced species, it is quite successful in its colonization of natural environments. It is considered native in California where it occurs only in natural habitats on the open coast and never on artificial substrates (G. LAMBERT 2005, personal communication).

Botrylloides nigrum was first recorded in Brazil in the states of Santa Catarina and São Paulo (RoDrigues 1962). In this study it was found on a cultivated mussel, and so possibly introduced. In Brazil, this species is usually epizooic, growing on algae and bivalve shells, such as oysters and mussels.

Styela canopus was first found at Ilha Grande, in Rio de Janeiro (Monniot 1969, 1970). Here, one sample was found on an abandoned fishnet on the ocean floor, suggesting that it was introduced. In São Sebastião, São Paulo, this species is found on artificial substrates used in scientific experiments (RMR, unpublished observation). MonNIOT (2002) described this species on wrecks on the coast near Djibouti, Africa. Styela partita (Stimpson, 1852) whose type location is Boston Harbor, in the 

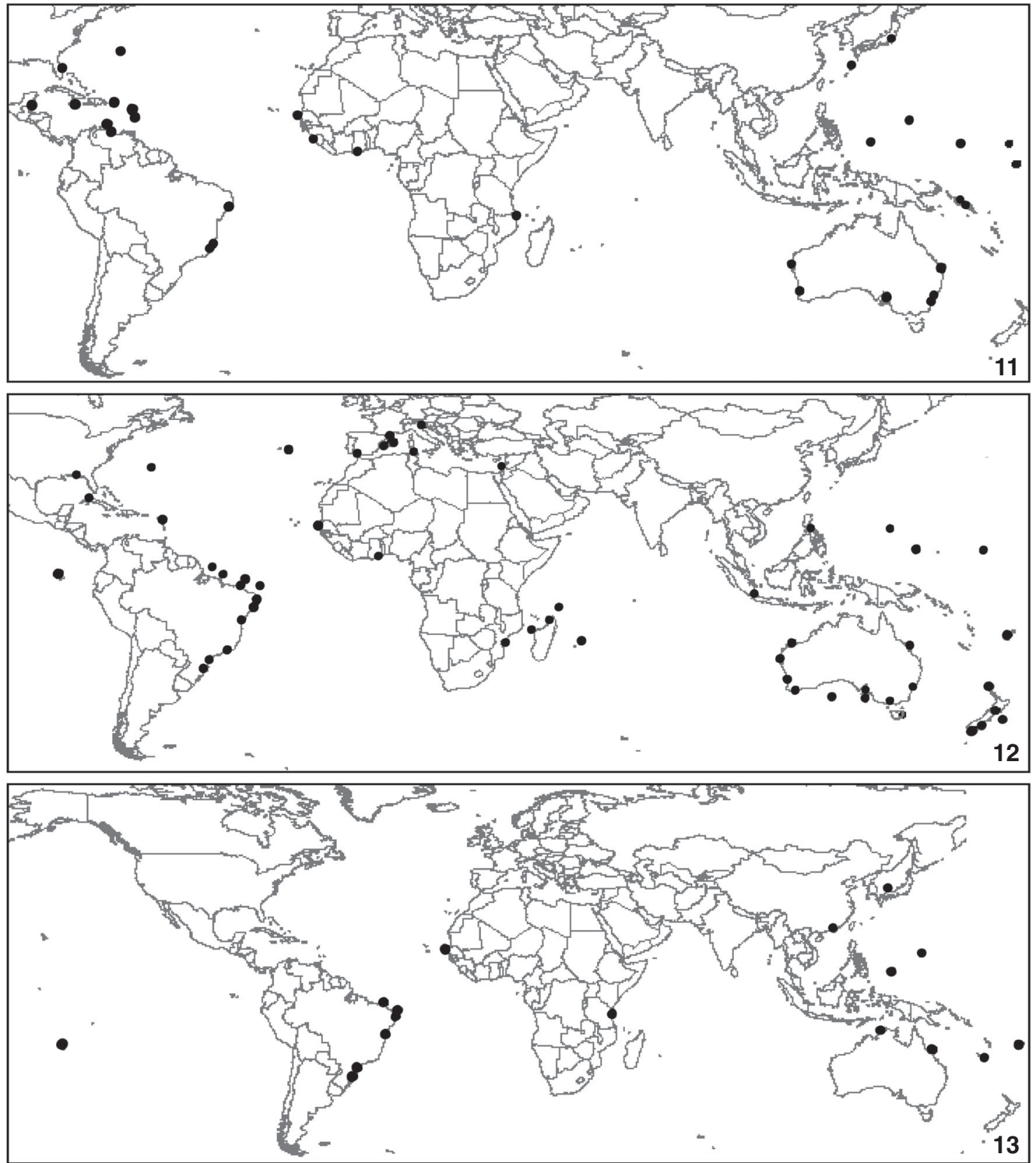

Figures 11-13. Distributions of the species found in Paranaguá Bay and nearby, with widespread and continuous distributions in the western Atlantic: (11) Perophora multiclathrata; (12) Cystodytes dellechiajei; (13) Didemnum granulatum.

United States and shows an affinity for ports (VAN NAME 1945), was one of the species later synonymized with $S$. canopus. Thus, it is quite probable that Styela canopus is an introduced species in the western Atlantic and therefore southern Brazil.

Microcosmus exasperatus was first found in Brazil by vaN NAme (1945) at São Francisco do Sul, Santa Catarina. The type locality is in the Caribbean, but its original distribution is un- known. Since many blanks exist in the distribution of this species, it is quite possible that it was introduced in a variety of places (MonNiot 1981). Its first Mediterranean record was in 1963 in the military port Bizerte, and after this record many others were recorded, usually in ports (MONNIOT 1981), indicating its recent introduction here. MonNIOT (1965) recorded this species on the west coast of Africa in Pointe-Noire, Congo, 

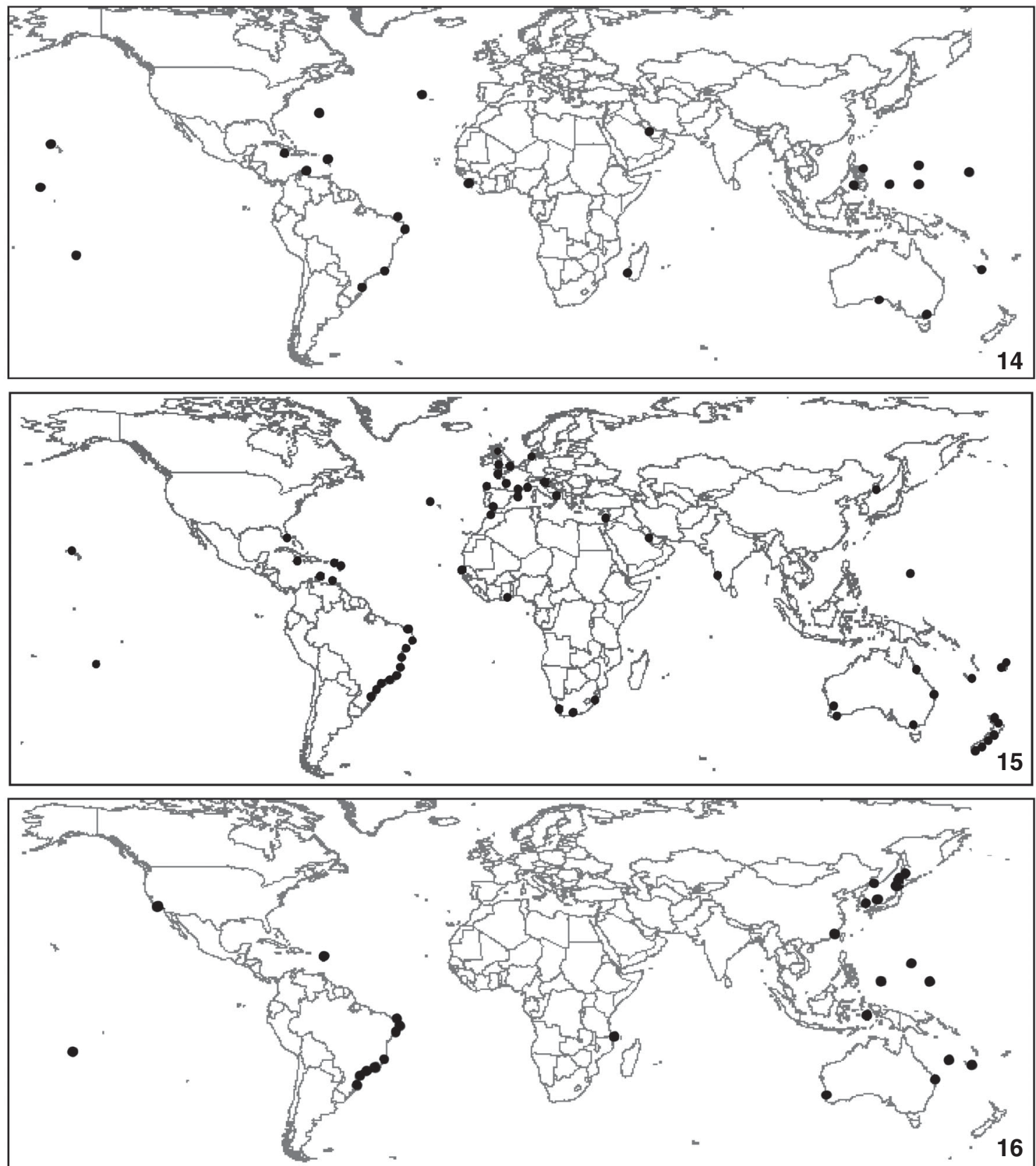

Figures 14-16. Distributions of the species found in Paranaguá Bay and nearby, with widespread and continuous distributions in the western Atlantic: (14) Lissoclinum fragile; (15) Diplosoma listerianum; (16) Botryllus tuberatus.

where rocky bottoms do not occur; it occurred only on the chains securing a floating dock, between $1-3$ m depth. In New Caledonia, this species is abundant only on wharves and buoys at the Noumea Port (MonNiot 1989).

Most species encountered in this study, with the exception of Eudistoma carolinense and Distaplia bermudensis, occur on at least one type of artificial substrate, such as cultures, artificial reefs or the substrates common to ports (piers, buoys, columns and boats, etc.). The species Ascidia curvata, A. sydneiensis, Botryllus planus and Clavelina oblonga occur on oyster cultures (Dalby \& Young 1993, Tokioka 1952); Cystodytes dellechiajei has been found on shrimp nets (Millar 1988); 

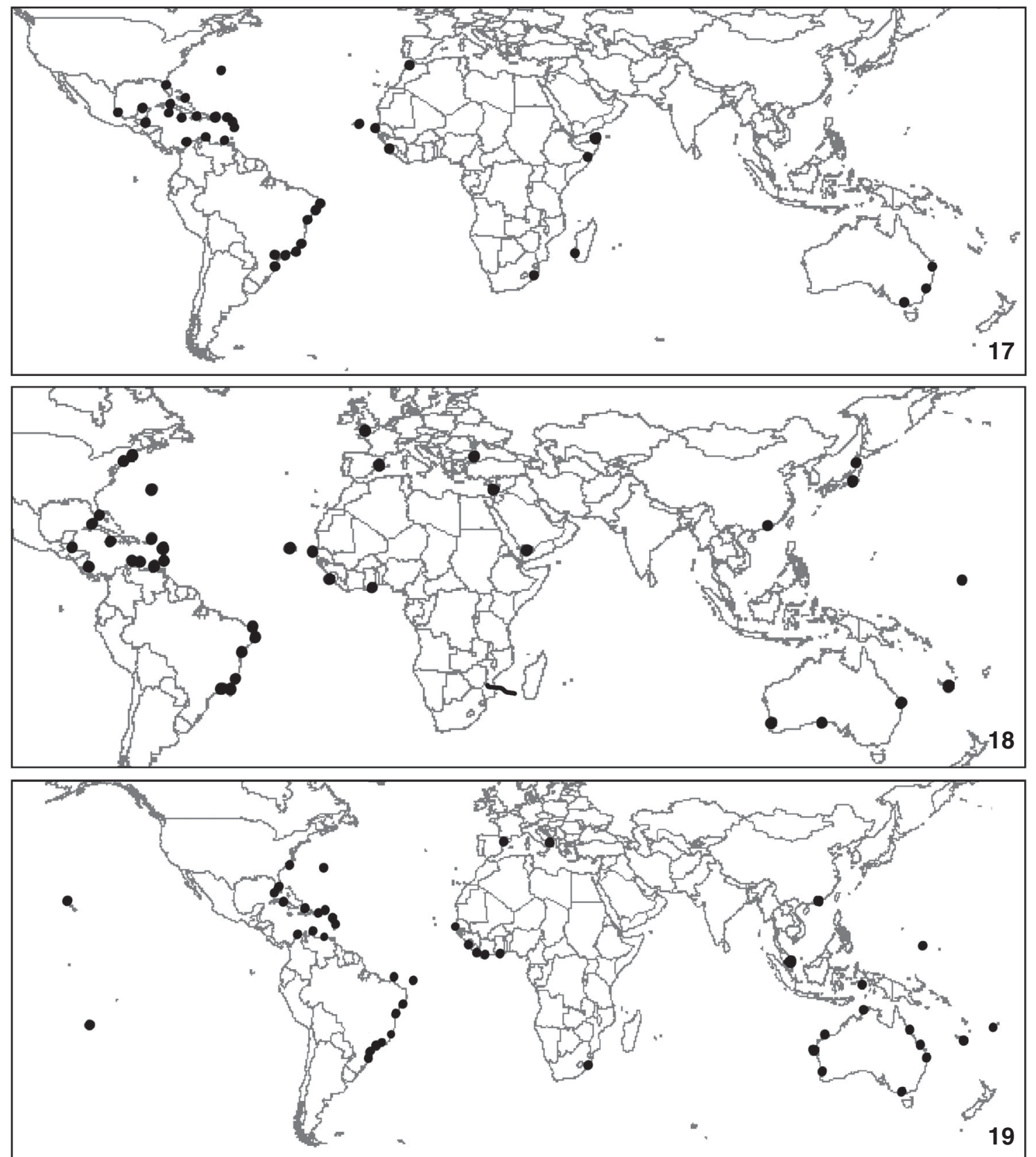

Figures 17-19. Distributions of the species found in Paranaguá Bay and nearby, with widespread and continuous distributions in the western Atlantic: (17) Botrylloides nigrum; (18) Styela canopus; (19) Microcosmus exasperatus.

Diplosoma listerianum was found on fish hatchery structures at Bahrain, in the Arabian Gulf (Monniot \& Monniot 1997). Cultures are very favorable for colonization by ascidians, since the substrates are simple and associated with ecological disturbances (LAMBERT 2001, 2005b). In at least one study, ascidians growing over cultured oysters did not influence the oyster growth rates
(DAlby \& Young 1993), yet in some circumstances the cover due to ascidians may be so great that they must exert a strong impact on the cultured animals.

Species' historical records are fundamental for determining introduction status. Unfortunately, only three studies prior to ours exist for ascidians in Paranaguá Bay region: Moure et al. 
(1954) recorded three species (Didemnum candidum Savigny, 1816; Polysyncraton amethysteum (van Name, 1902) and Styela plicata). Only the latter has been found again, with one individual on a mussel culture (Perna perna Linnaeus, 1758). This species is apparently not very successful in the region. Didemum candidum is really a group of poorly identified species and which makes any interpretation difficult. While not found in our study, Polysyncraton amethysteum may be found in nearby Guaratuba Bay.

An experimental study of the encrusting community on artificial plates in Paranaguá Bay found Clavelina oblonga, Didemnum speciosum, Diplosoma singulare Lafargue, 1968, Polyclinum constellatum Savigny, 1816, Styela plicata, Symplegma viride Herdman, 1886 (probably Symplegma brakenhielmi) (M. D. Correia 1989, unpublished data). Of these, only Clavelina oblonga and Styela plicata were found in this study and were considered cryptogenic and introduced, respectively. Clavelina oblonga may actually be native, since it is abundant in all areas of the study.

The most recent study of ascidians in the bay includes the following species: Praia de Encantadas, Ilha do Mel: Ascidia curvata, Ascidia sydneiensis, Clavelina oblonga, Didemnum granulatum, Didemnum lutarium van Name, 1910, Diplosoma listerianum, Distaplia bermudensis, Cystodytes dellechiajei, Praia de Fora, Ilha do Mel: Symplegma rubra Monniot C, 1972 and Ilha da Figueira: Microcosmus exasperatus (RocHA \& NASSER 1998). The differences between that study and this one my be due to two, not mutually exclusive reasons. First, neither study was intensive over the long term, and so it is not surprising that all existing species are not recorded in either of them. Second, some of the species may have been introduced since 1998. A comparison between the species found within the bay (Ilha das Cobras and Pier Tenenge) and on nearby islands (Ilha do Mel and Galheta), finds that Perophora multiclathrata, Distaplia bermudensis, Lissoclinum fragile, Botryllus planus and Symplegma rubra were found only within the bay, which strongly suggests introduction. On the other hand, D. bermudensis was once found on Ilha do Mel (Rocha \& NASSER 1998), B. planus is often found on rocky shores in Guaratuba, where $P$. muticlathrata has also been found. $P$. muticlathrata, however, is a cryptic species and will require a greater effort to be consistently found.

Comparing the ascidian fauna from Paranaguá Bay with that found in the more southern, isolated from ship traffic, Arvoredo Biological Reserve (RocHA et al. 2005), of the 18 species reported here, 12 were found at the reserve: Clavelina oblonga, Eudistoma carolinense, Cystodytes dellechiajei, Distaplia bermudensis, Didemnum granulatum, Diplosoma listerianum, Lissoclinum fragile, Botrylloides nigrum, Botryllus tuberatus, Botryllus planus, Styela canopus and Microcosmus exasperatus. Since many of these species are considered cryptogenic or introduced in southern Brazil, a monitoring program of the reserve could be very informative to understand the population dynamics of these species, and any potential problems associated with their introductions.
Among the ascidian species that are the most common introduced species worldwide, four were found in Paranaguá Bay: Diplosoma listerianum, Styela canopus, Styela plicata and Microcosmus exasperatus. This indicates that the Paranaguá Port is open to invasion of exotic species, and should be thoroughly monitored to understand the growth and recruitment of introduced populations, and to understand how to control those populations if it is deemed necessary. Since more groups of organisms besides ascidians, including many benthic invertebrates, are probably involved in these introductions, we urgently recommend a much needed larger scale inventory of the fauna potentially influenced by port activities. Only with such an inventory will we be prepared to undertake the necessary measures should we discover potentially harmful and economically costly introduced organisms.

\section{ACKNOWLEDGEMENTS}

We thank Rafael Metri and Jim Roper for assistance in the field, Tatiane R. Moreno for helping with species identification, Suzana B. Farias for helping with geographical coordinates and Gretchen Lambert for suggestions to the manuscript. CNPq provided a grant for RMR (process 473408/2003-01) and a scholar ship to LPK.

\section{REFERENCES}

BALDOCK, B. \& J.D.D. BISHOP. 2001. Occurrence of the non-native ascidian Perophora japonica in the Fleet, southern England. Journal of the Marine Biological Association of the United Kingdom, Cambridge, 81 (6): 1067.

Berrill, N.J. 1975. Chordata: Tunicata, p. 241-282. In: A.C. GIESE $\&$ J.S. PEARSE (Eds). Reproduction of Marine Invertebrates. Entoprocts and Lesser Invertebrates. New York, Academic Press, vol. 2.

Berrill, N.J. \& A. Cohen. 1936. Regeneration in Clavelina lepadiformis. Journal of Experimental Biology, Cambridge, 13: 352-362.

BjoRnBERG, T.K.S. 1956. Ascídias da costa sul do Brasil (nota prévia). Ciência \& Cultura, São Paulo, 8 (3): 164-65.

BrunetTi R.H. 1978-1979. Polyandrocarpa zorritensis (Van Name, 1931), a colonial ascidian new to the Mediterranean record.. Vie Milieu, Banyuls-sur-Mer, 28-29 (4AB): 647-652.

Brunetti, R. \& F. Mastrototaro. 2004. The non-indigenous stolidobranch ascidian Polyandrocarpa zorritensis in the Mediterranean: description, larval morphology and pattern of vascular budding. Zootaxa, Auckland, 528: 1-8.

Casas, G.; R. Scrosati \& M.L. Piriz. 2004. The invasive kelp Undaria pinnatifida (Phaeophyceae, Laminariales) reduces native seaweed diversity in Nuevo Gulf (Patagonia, Argentina). Biological Invasions, Dordrecht, 6: 411-416.

Carlton, J.T. \& J.B. Geller. 1993. Ecological roulette: Biological invasion and the global transport of nonindigenous marine organisms. Science, Washington, 261: 78-82. 
Costa, H.R. 1969. Notas sobre os Ascidiacea brasileiros. V. Subclasse Pleurogona._Atas da Sociedade de Biologia do Rio de Janeiro, Rio de Janeiro, 12 (5-6): 299-302.

Culver, C.S. \&. A.M. KurIs. 2000. The apparent eradication of a locally established introduced marine pest. Biological Invasions, Dordrecht, 2: 245-253.

Dalby, J.E. \& C.M. Young. 1993. Variable effects of ascidians competitors on oysters in a Florida epifaunal community. Journal of Experimental Marine Biology and Ecology, Amsterdam, 167: 47-57.

Davis M.H. \& M.E. DAvis. 2005. Styela clava (Tunicata: Ascidiacea) a new addition to the fauna of the Portuguese coast. Journal of the Marine Biological Association of the United Kingdom, Cambridge, 85: 403-404.

Fernandes, L.F.; L. Zehnder-Alves \& J. BAssfeld. 2001. The recently established diatom Coscinodiscus wailesii (Coscinodiscales, Bacillariophyta) in Brazilian waters. I: remarks on morphology and distribution. Phycological Research, Carlton South, 49 (2): 89.

Floeter, S.R. \& A. Soares-Gomes. 1999. Biogeographic and species richness patterns of Gastropoda on the southwestern Atlantic. Revista Brasileira de Biologia, Rio de Janeiro, 59 (4): 567-575.

Harris, L.G. \& M.C. Tyrrell. 2001. Changing community states in the Gulf of Maine: synergism between invaders, overfishing and climate change. Biological Invasions, Dordrecht, 3: 921.

Herdman, W.A. 1886. Report on the Tunicata collected during the voyage of the H.M.S. Challenger during the years 1873-1876. Part II. Ascidiae compositae. Edinburg, Report of the Scientific Results of the Voyage of H.M.S. Challenger during the years 1873-76, vol. 14, 429p.

Kотт, P. 1985. The Australian Ascidiacea part 1, Phlebobranchia and Stolidobranchia. Memoirs of the Queesland Museum, Brisbane, 23: 1-440.

Котт, P. 1990. The Australian Ascidiacea, part 2, Aplousobranchia (1). Memoirs of the Queesland Museum, Brisbane, 29 (1): 1-226.

Lambert, C.C. \& G. Lambert. 1998. Non-indigenous ascidians in southern California harbors and marinas. Marine Biology, Berlim, 130: 675-688.

Lambert, C.C. \& G. Lambert. 2003. Persistence and differential distribution of nonindigenous ascidians in harbors of the Southern California Bight. Marine Ecology Progress Series, Oldendorf, 259: 145-161.

LAmbert, G. 2001. A global overview of ascidians introductions and their possible impact on the endemic fauna, p. 249257. In: H. Sawada; H. Yokosawa \& C.C. Lambert (Eds). The Biology of Ascidians, Tokyo, Springer Verlag, XXVII+470p.

LAMBERT, G. 2002. Nonindigenous ascidians in tropical waters. Pacific Science, Honolulu, 56 (3): 291-298.

LAmbert, G. 2003. Marine biodiversity of Guam: the Ascidiacea. Micronesica, Mangilao, 35-36: 588-597.
LAmbert, G. 2004. The south temperate and Antarctic ascidian Corella eumyota reported in two harbours in north-western France. Journal of the Marine Biological Association of the United Kingdom, Cambridge, 84: 239-241.

Lambert, G. 2005a. First North American record of the ascidian Perophora japonica. Journal of the Marine Biological Association of the United Kingdom, Cambridge, 85 (4825): 1-2.

LAMBERT, G. 2005b. Ecology and natural history of the protochordate. Canadian Journal of Zoology, Ottawa, 83: 3450.

López-Legentil, S. \& X. Turon. 2005. How do morphotypes and chemotypes relate to genotypes? The colonial ascidian Cystodytes (Ascidiacea: Polycitoridae). Zoologica Scripta, Kidlington, 34: 3-14.

McDonald, J. 2004. The invasive pest species Ciona intestinalis (Linnaeus, 1767) reported in a harbour in southern western Australia. Marine Pollution Bulletin, Kidlington, 49: 854874.

MilLAR, R.H. 1956. XLVIII - Notes on some ascidians from Sierra Leone and Gambia. Annals and Magazine of Natural History, London, 12 (9): 409-417.

Millar, R.H. 1958. Some ascidians from Brazil. Annals and Magazine of Natural History, London, 13: 497-514.

Millar, R.H. 1971. The biology of ascidians. Advances in Marine Biology, San Diego, 9: 1-100.

Millar, R.H. 1977. Ascidians (Tunicata: Ascidiacea) from the Northern and North-eastern Brazilian Shelf. Journal of Natural History, London, 11: 169-223.

Millar, R.H. 1988. Ascidians collected during the International Indian Ocean Expedition. Journal of Natural History, London, 22: 823-848.

Monniot, C. 1965. Etude systématique et évolutive de la famille des Pyuridae (Ascidiacea). Mémoires du Muséum National d'Histoire Naturelle, Paris, Sér. A, 36: 1-203.

Monniot, C. 1969-1970. Ascidies Phlébobranches et Stolidobranches. In: Résultats Scientifiques des Campagnes de la Calypso. Annales de l'Institut Océanographique, Paris, 47: 33-59.

Monniot, C. 1981. Apparition de l'ascidie Microcosmus exasperatus dans les ports mediterranéens. Tethys, Marseille, 10 (1): 59-62.

Monniot, C. 1989. Ascidies de Nouvelle-Calédonie. 6. Pyuridae et Molgulidae. Bulletin du Muséum National d'Histoire Naturelle, Paris, Sér. 4, 11A (3): 475-507.

Monniot, C. 2002. Stolidobranch ascidians from the tropical western Indian Ocean. Zoological Journal of the Linnean Society, London, 135: 65-120.

Monniot, C. \& F. Monniot. 1983. Navigation ou courants? La colonization des Açores et des Bermudes par les Ascidies (tuniciers benthiques). Comptes Rendus des Seances de la Societé de Biogéographie, Paris, 59 (1): 53-58

Monniot, C. \& F. Monniot. 1985. Apparition de l'ascidie Perophora japonica sur les cotês et dans les ports de la Manche. Comptes 
Rendus des Seances de la Societé de Biogéographie, Paris, 61 (3): 111-116.

Monniot, C.; F. Monniot \& P. Laboute. 1985. Ascidies du port de Papeet (Polynésie Française): relation avec le mileu naturel et apports intercontinentaux par la navigation. Bulletin du Muséum National d'Histoire Naturelle, Paris, 4a Sér., Sec A, 7 (3): 481-495.

Monniot, C.; F. Monniot \& P. Laboute. 1991. Coral Reef Ascidians of New Caledonia. Coléction Faune Tropicale XXX, Orstom Editions, Paris, 247p.

Monniot, C. \& F. Monniot. 1994. Additions to the inventory of eastern tropical Atlantic ascidians; arrival of cosmopolitan species. Bulletin of Marine Science, Lawrence, 54 (1): $71-$ 93.

Monniot, C. \& F. Monniot. 1997. Record of ascidians from Bahrain, Arabian Gulf with three new species. Journal of Natural History, London, 31: 1623-1643.

Monniot, F. 1992. Ascidies de Nouvelle-Caledonie. 12. Le genre Lissoclinum (Didemnidae) dans de lagon sud. Bulletin du Muséum National d'Histoire Naturelle, Paris, 4 ser, 14A (3-4): 565-589.

Monniot, F. \& C. Monniot. 1997. Ascidians collected in Tanzania. Journal of East African Natural History, Dar Es Salaam, 86: 1-35.

Monniot, F. \& C. Monniot. 2001. Ascidians from the tropical western Pacific. Zoosystema, Paris, 23 (2): 201-383.

Moure, J.S.; T.K.S. BJornberg \& T.ST. Loureiro. 1954. Protochordata ocorrentes na entrada da Baía de Paranaguá. Dusenia, Curitiba, 5 (5-6): 233-242.

NishikaWa, T.; Y. KajIWARa \& K. KaWamura. 1993. Probable introduction of Polyandrocarpa zorritensis (Van Name) to Kitakyushu and Kochi, Japan. Zoological Science, Tokyo, 10: 176.

Palacio, J.F. 1982. Revisión zoogeográfica marina del sur del Brasil. Boletim do Instituto Oceanográfico da Universidade de São Paulo, São Paulo, 31 (1): 69-92.

PÉRÈs, J.M. 1957. Ascidies récoltées dans les parages des Baléares par le professeur Lacaze-Duthiers. (Deuxième partie: Iviza et San Antonio). Vie Milieux, Banyuls-sur-Mer, 6 (Supl.): 223-234.

RocHA, R.M. 1991. Replacement of the compound ascidian species in a southeastern Brazilian fouling community. Boletim do Instituto Oceanográfico, São Paulo, 39 (2): 141-153.

Rocha, R.M. 2002. Bostricobranchus digonas, Abbott 1951 (Ascidiacea, Molgulidae) in Paranaguá Bay, Paraná, Brazil. A case of recent invasion? Revista Brasileira de Zoologia, Curitiba, 19 (1): 157-161.

Rосна, R.M. \& L.V.G. Costa. 2005. Ascidians from Arraial do Cabo, RJ, Brazil. Iheringia, Série Zoologia, Porto Alegre, 95 (1): 57-64.

Rocha, R.M. \& F. MonNiot. 1995. Taxonomic and ecological notes on some Didemnum species (Ascidiacea, Didemnidae) from São Sebastião Channel, South-Eastern Brazil. Revista Brasileira de Biologia, Rio de Janeiro, 55 (4): 639-649.
Rocha, R.M. \& T.R. Moreno. 2000. Ascidians associated with Eudistoma carolinense Van Name, 1945 (Ascidiacea, Polycitoridae). Description of species and ecological notes. Ophelia, Elsinore, 52: 9-16.

Rocha, R.M. \& C.M. Nasser. 1998. Some ascidians (Tunicata, Ascidiacea) from Paraná state, southern Brazil. Revista Brasileira de Zoologia, Curitiba, 15 (3): 633-642.

Rocha, R.M.; T.R. Moreno \& R. Metri. 2005. Ascídias (Tunicata) da Reserva Biológica Marinha do Arvoredo, Santa Catarina, Brasil. Revista Brasileira de Zoologia, Curitiba, 22 (2): 461476.

Rodrigues, S.A. 1962. Algumas ascídias do litoral sul do Brasil. Boletim da Faculdade de Filosofia Ciências e Letras da Universidade de São Paulo, São Paulo, série botânica 24: 193-216.

Rodrigues, S.A. \& R.M. Rocha. 1993. Littoral compound ascidians (tunicata) from São Sebastião, Estado de São Paulo, Brazil. Proceedings of the Biological Society of Washington, Washington, 106: 728-739.

Rodrigues, S.A.; R.M. Rocha \& T.M.C. Lotufo. 1998. Guia ilustrado para identificação das ascídias do Estado de São Paulo. São Paulo, FAPESP, 190p.

Ross, D.J.; C.R. Johnson \& C.L. Hewitt. 2003. Assessing the ecological impacts of an introduced seastar: the importance of multiple methods. Biological Invasions, Dordrecht, 5: 3-21.

Rowe, F.W.E. 1966. A review of the genus Diplosoma Macdonald, 1859 with a description of the proposed new type Diplosoma listerianum. Annals and Magazine of Natural History, London, 9 (103): 457-467.

Ruiz, G.M; P. Fofonoff; J.T. Carlton; M.J. Wonham \& A.H. Hines. 2000. Invasion of coastal marine communities in North America: Apparent Patterns, Processes and Biases. Annual Review of Ecology and Systematics, Palo Alto, 31: 481531.

Sommerfeldt, A.D. \& J.D.D. Bishop. 1999. Random amplified polymorphic DNA (RAPD) analysis reveals extensive natural chimerism in a marine protochordate. Molecular Ecology, Oxford, 8: 885-890.

TокіокA, T. 1952. Ascidians collected by Messrs Renzi Wada and Seizi Wada from the pearl-oyster bed in the Arafura Sea in 1940. Publications of the Seto Marine Biological Laboratory, Wakayama, 2: 91-142.

TокіокA, T. 1967. Pacific Tunicata of the United States National Museum. United States National Museum Bulletin, Washington, 251: 1-247.

Traustedt, M.P.A. 1883. Vestindiske Ascidiae simplices. Anden afdeling. Molgulidae og Cynthiadae. Videnskabelige Meddelelser fra Dansk Naturhistoriske Forening, Copenhagen, 1882: 108-36.

Turon, X. 1992. Periods of non-feeding in Polysyncraton lacazei (Ascidiacea: Didemnidae) a rejuvenative process?. Marine Biology, Berlim, 112: 647-655. 
Turon, X.; I. Tarjuelo; S. Duran \& M. Pascual. 2003. Characterising invasion processes with genetic data: an Atlantic clade of Clavelina lepadiformis (Ascidiacea) introduced into Mediterranean harbours. Hydrobiologia, Dordrecht, 503: 29-35.

VAN NAME, W.G. 1945. The North and South American ascidians. Bulletin of the American Museum of Natural History, New York, 84: 1-476.

Received in 11.III.2005; accepted in 07.XII.2005.
Wasson, K.; C.J. Zabin; L. Bedinger; M.C. Diaz \& J.S. Pearse. 2001. Biological invasions of estuaries without international shipping: the importance of intraregional transport. Biological Conservation, Kidlington, 102 (2): 143-153.

Zvyagintsev, A.Yu.; K.E. Sanamyan \& M.D. Koryakova. 2003. The introduction of the ascidians Molgula manhattensis (De Kay, 1843) into Peter the Great Bay (Sea of Japan). Sessile Organisms, 20 (1): 7-10. 